\title{
D-Aspartate Regulates Melanocortin Formation and Function: Behavioral Alterations in D-Aspartate Oxidase- Deficient Mice
}

\author{
Alex S. Huang, ${ }^{1}$ Anne Beigneux, ${ }^{4 *}$ Zachary M. Weil,${ }^{5 *}$ Paul M. Kim, ${ }^{2}$ Mark E. Molliver, ${ }^{1}$ Seth Blackshaw, ${ }^{1}$ \\ Randy J. Nelson, ${ }^{5 * *}$ Stephen G. Young, ${ }^{4 * *}$ and Solomon H. Snyder ${ }^{1,2,3}$ \\ Departments of ${ }^{1}$ Neuroscience, ${ }^{2}$ Pharmacology, and ${ }^{3}$ Psychiatry and Behavioral Sciences, The Johns Hopkins University School of Medicine, Baltimore, \\ Maryland 21205, ${ }^{4}$ Department of Medicine, Division of Cardiology, David Geffen School of Medicine, University of California, Los Angeles, California \\ 90095, and ${ }^{5}$ Departments of Psychology and Neuroscience, Institute for Behavioral Medicine Research, The Ohio State University, Columbus, Ohio 43210
}

D-Aspartate, an abundant D-amino acid enriched in neuroendocrine tissues, can be degraded by D-aspartate oxidase (Ddo). To elucidate the function of D-aspartate, we generated mice with targeted deletion of $D d o\left(D d o^{-/}\right)$and observe massive but selective augmentations of D-aspartate in various tissues. The pituitary intermediate lobe, normally devoid of D-aspartate from endogenous $D d o$ expression, manifests pronounced increases of immunoreactive $\mathrm{D}$-aspartate in $D d o^{-/-}$mice. $D d o^{-/-}$mice show markedly diminished synthesis and levels of pituitary proopiomelanocortin $/ \alpha$-MSH, associated with decreased melanocortin-dependent behaviors. Therefore, Ddo is the endogenous enzyme that degrades D-aspartate, and Ddo-enriched organs, low in D-aspartate, may represent areas of high turnover where D-aspartate may be physiologically important.

Key words: amino acid; neuroendocrine; knock-out mice; aspartate; turnover; behavior; proopiomelanocortin (POMC)

\section{Introduction}

D-Enantiomer amino acids, previously thought to occur only in bacteria, have recently been demonstrated in mammals (Dunlop et al., 1986). D-Serine is an apparent glial neurotransmitter/neuromodulator in the brain and is synthesized by serine racemase, a pyridoxal 5' -phosphate-dependent enzyme that racemizes L- to D-serine (Wolosker et al., 1999). In physiological conditions, D-serine is degraded by D-amino acid oxidase (Dao) such that Dao-deficient mice display increased levels of D-serine (Hashimoto et al., 1993).

$\mathrm{D}$-Aspartate is the only other abundant $\mathrm{D}$-amino acid found in mammals, with the highest levels found in the adrenals, brain, pineal, pituitary, retina, and testes (Hashimoto and Oka, 1997). Immunohistochemical studies have identified discrete cellular localizations of D-aspartate including adrenal medulla epinephrine cells, hypothalamic paraventricular (PVN) and supraoptic (SON) nuclei, and testicular elongate spermatids (Schell et al., 1997; Sakai et al., 1998). In the pituitary, D-aspartate is concentrated in the posterior lobe $(\mathrm{PL})$ and in scattered cells of the

\section{Received Nov. 18, 2005; revised Jan. 16, 2006; accepted Jan. 17, 2006.}

This work is supported by United State Public Health Service Grant DA00266 and Research Scientist Award DA00074 (S.H.S.); National Institutes of Health (NIH) Grants MH57535 and MH66144 and National Science Foundation Grant 04-16897 (R.J.N.); and NIH Grants CA099506, AR050200, and AI054384 (S.G.Y.). We thank Krishna Juluri, Makoto E. Hara, Sangwon F. Kim, Daniel M. Lerman, and Seema Kaura for helpful discussions.

${ }^{*}$ A.B. and Z.M.W. contributed equally to this work.

**S.G.Y. and R.J.N. contributed equally to this work.

Correspondence should be addressed to Solomon H. Snyder, Department of Neuroscience, The Johns Hopkins University School of Medicine, 725 North Wolfe Street, Baltimore, MD 21205. E-mail: ssnyder@jhmi.edu.

DOI:10.1523/JNEUROSCI.5060-05.2006

Copyright $\odot 2006$ Society for Neuroscience $\quad$ 0270-6474/06/262814-06\$15.00/0 anterior lobe $(\mathrm{AL})$, with negligible levels in the intermediate lobe (IL) (Schell et al., 1997; Lee et al., 1999).

Physiologic activities responsible for metabolizing D-aspartate are not definitively established. In vitro, D-aspartate oxidase (Ddo), a flavin adenine dinucleotide-dependent peroxisomal enzyme, displays selective oxidative activity toward acidic D-amino acids (Simonic et al., 1997). It is expressed at highest levels in the kidney, liver, brain, and pituitary IL (Schell et al., 1997). The absence of potent and selective Ddo inhibitors hinders investigations into the physiologic role of D-aspartate.

In the present study, we describe the generation of mutant mice $\left(D d o^{-/-}\right)$with targeted deletion of Ddo and demonstrate massive, selective augmentations of $\mathrm{D}$-aspartate levels in numerous tissues. In $D d o^{-1-}$ mice, the pituitary IL displays substantial $\mathrm{D}$-aspartate, which is undetectable in wild-type mice. The pituitary IL contains almost exclusively melanotropes, which generate proopiomelanocortin (POMC) as the sole source of pituitary $\alpha$-melanocyte-stimulating hormone ( $\alpha$-MSH), a member of the melanocortin peptide family (Hadley and Haskell-Luevano, 1999). Melanocortins mediate several behaviors including penile erection (Martin and MacIntyre, 2004), autogrooming (Spruijt et al., 1992), and weight loss (Vergoni et al., 2000). Elevated $\mathrm{D}$-aspartate levels in the $\mathrm{Ddo} \mathrm{o}^{-/-}$pituitary IL lead to diminished POMC/ $\alpha-\mathrm{MSH}$ as well as melanocortin-dependent behaviors, thereby establishing physiologic functions for D-aspartate.

\section{Materials and Methods}

Generation of Ddo-deficient mice. A human DDO cDNA (GenBank accession number D89858) was used to identify a bacterial artificial chromosome (BAC) clone that spanned the mouse Ddo gene. The gene-targeting 
vector was prepared as follows: the short arm, a $1.9 \mathrm{~kb}$ SpeI fragment containing $\sim 1.3 \mathrm{~kb}$ upstream and $\sim 500 \mathrm{bp}$ downstream from exon 2, was subcloned into EcoRI-BamHI-digested pKSloxPNT. The long arm, a $5 \mathrm{~kb} \mathrm{NcoI-BamHI}$ fragment containing the middle of intron 3 to the $5^{\prime}$ region of intron 4, was subcloned into SmaI-BamHI-digested pBluescript II (Stratagene, La Jolla, CA). The latter plasmid was cleaved with EcoRV and NotI, generating a $5 \mathrm{~kb}$ insert that was cloned into AscI-NotIdigested pKSloxPNT. The orientation of both arms was verified by DNA sequencing and restriction endonuclease mapping.

The sequence-replacement gene-targeting vector was linearized with NotI and electroporated into mouse embryonic stem (ES) cells (strain 129/SvJae). Mouse ES cells were cultured on mitomycin C-treated STO feeder cells in medium containing G418 $(250 \mu \mathrm{g} / \mathrm{ml})$ and 1-(2'-deoxy2 'fluoro- $\beta$-D-arabinofuranosyl)-5-iodouracil $(0.2 \mu \mathrm{M})$. Drug-resistant ES cell colonies were picked $10 \mathrm{~d}$ after electroporation. Targeted colonies $\left(\mathrm{Ddo}^{+/-}\right)$were identified by Southern blot analysis of BamHI-digested genomic DNA with a $5^{\prime}$-flanking probe amplified from BAC DNA with primers 5'-AGG GTG AAA AGC AAT CTG TGG CTA A-3' and 5'-GCA GAG AGG CAG TTC CAC AGA GCT T-3'. Four targeted clones, each with a single integration event, were injected into C57BL/6 blastocysts to produce chimeric mice, which were bred to establish lines of Ddo knockout mice.

Northern blot and in situ hybridization. $\left[\alpha-{ }^{32} \mathrm{P}\right] \mathrm{dCTP}-$ (All-in-One random prime labeling mix; Sigma, St. Louis, MO) and/or digoxigeninlabeled (Dig-labeling kit; F. Hoffmann-La Roche, Basel, Switzerland) mouse full-length POMC or Ddo (spanning exons 2-4) probes were synthesized. Mouse Ddo cDNA template was amplified by reverse transcriptase-PCR from mouse liver RNA with primers $5^{\prime}$-CGT TGG AGC TGG CGT GAT AGG-3' and 5'-TCC AGC CAC GGG AGG TAG GC-3'.

Total RNA was isolated from mouse tissue (Tri Reagent; Sigma), and $25 \mu \mathrm{g}$ was separated by electrophoresis on a $1 \%$ agarose/formaldehyde gel and transferred onto Nytran SuPerCharge membrane (Schleicher \& Schuell, Dassel, Germany). An 18 S cDNA probe was used as controls for RNA integrity and loading.

Fresh-frozen mouse pituitary sections $(20 \mu \mathrm{m})$ were fixed in $4 \%$ paraformaldehyde and acetylated in $0.1 \mathrm{~m}$ triethanolamine, $\mathrm{pH} 8$, with $0.25 \%$ acetic anhydride. Probe binding was determined by alkaline phosphatase-conjugated anti-digoxigenin Fab fragments (1:5000; F. Hoffmann-La Roche). Standard prehybridization, hybridization, washing, and visualization procedures were used.

Immunoblotting. Kidney/liver and pituitary were respectively homogenized in (1) $5 \times$ vol of $50 \mathrm{~mm}$ Tris, $\mathrm{pH} 8.5$, and $250 \mathrm{~mm}$ sucrose or (2) 100 $\mu \mathrm{l}$ of 50 mм Tris, pH 7.5, 2 mм EDTA, $100 \mu \mathrm{M}$ PMSF, $100 \mathrm{~mm} \mathrm{NaCl}, 1 \mathrm{~mm}$ DTT, and 1 protease inhibitor cocktail tablet (F. Hoffmann-La Roche) with a glass/Teflon homogenizer. Kidney/liver P2 fractions (75 $\mu \mathrm{g})$ and crude pituitary lysate $(10$ or $50 \mu \mathrm{g})$ were separated by SDS-PAGE followed by transfer onto $0.45 \mu \mathrm{m}$ nitrocellulose (Bio-Rad, Hercules, CA) or applied to $0.45 \mu \mathrm{m}$ polyvinylidene difluoride (Immobilon-P; Millipore, Bedford, MA) with a Minifold-I slot blot apparatus (Schleicher \& Schuell). Standard blocking and washing procedures were used, and bands were visualized by ECL (Pierce, Rockford, IL).

An antibody against Ddo was generated with a peptide corresponding to Ddo amino acids 73-89 (Johns Hopkins University School of Medicine Biosynthesis Core Facility). The peptide was conjugated to maleimide-activated KLH (Pierce) and injected into rabbits. Sera from Cocalico Biologicals (Reamstown, PA) were affinity-purified for Western blots $(15 \mu \mathrm{g} / \mathrm{ml})$. Other antibodies included mouse anti-cytochrome $c$ (1:700; Invitrogen, San Diego, CA), mouse anti- $\beta$-tubulin (1:5000; Upstate Biotechnology, Lake Placid, NY), rabbit anti-glyceraldehyde-3phosphate dehydrogenase (Hara et al., 2005) (1:2000), rabbit antiPOMC precursor (1:750; Phoenix Pharmaceuticals, Mountain View, $\mathrm{CA})$, rabbit anti- $\alpha$-MSH (1:750; Biogenesis, Kingston, $\mathrm{NH})$, and donkey anti-rabbit/mouse HRP (1:3000; Amersham Biosciences, Arlington Heights, IL)

Immunohistochemistry. D-Aspartate immunohistochemistry was conducted as described previously (Schell et al., 1997). Mice were perfused with $37^{\circ} \mathrm{C} 5 \%$ glutaraldehyde $/ 0.5 \%$ paraformaldehyde. Organs were postfixed for $2 \mathrm{~h}$ and cryoprotected. Free-floating sections $(45 \mu \mathrm{m})$ were quenched with $0.1 \% \mathrm{H}_{2} \mathrm{O}_{2}$ in methanol/PBS, reduced with $0.5 \% \mathrm{NaBH}_{4}$, blocked ( $4 \%$ NGS and $0.2 \%$ Triton X-100 in TBS), and incubated with a D-aspartate antibody $(1: 750)$ overnight $\left(4^{\circ} \mathrm{C}\right)$ in the presence of $\mathrm{L}$-aspartate-glutaraldehyde conjugate $(200 \mu \mathrm{M})$. Labeling was visualized with the Vectastain Elite kit (Vector Laboratories, Burlingame, CA). Specificity was determined by abolishing signal with $\mathrm{D}$-aspartate-glutaraldehyde conjugate $(200 \mu \mathrm{M})$.

For immunofluorescence, acetone-fixed fresh-frozen pituitary sections $(20 \mu \mathrm{m})$ were blocked for $1 \mathrm{~h}(10 \%$ NGS, $2 \%$ BSA, $0.1 \%$ Triton $\mathrm{X}-100)$, incubated with the above rabbit anti- $\alpha$-MSH antibody, and labeled with anti-rabbit Alexa-flour 488 antibody (1:300; Invitrogen).

HPLC amino acid analyses. Mouse organs were homogenized into $10 \times$ v/w $10 \%$ TCA $\left(4^{\circ} \mathrm{C}\right)$ and centrifuged at $25,000 \times g$. Five water-saturated ether extractions were conducted on the supernatant, which was then evaporated to completion by speed vacuum. Samples resuspended in HPLC-grade water were combined with $o$-phthaldialdehyde (Sigma) and Boc-Cys-OH (Calbiochem, La Jolla, CA) in $400 \mathrm{~mm}$ boric acid, $\mathrm{pH} 9$, and separated/analyzed by reverse-phase $\mathrm{C}_{18}$ HPLC (Schell et al., 1997).

In the castration experiment, 4-month-old male $\mathrm{Ddo} \mathrm{o}^{-1-}$ mice were castrated or sham-castrated under ether anesthesia. Mice were allowed to rest and feed ad libitum for $30 \mathrm{~d}$, after which kidneys were processed as above.

Testosterone analyses. Blood was drawn from the retroorbital sinus under isoflurane anesthesia into heparin. Samples were spun at $735 \times g$ for $25 \mathrm{~min}$ at $4^{\circ} \mathrm{C}$ and stored at $-80^{\circ} \mathrm{C}$ until enzyme immunoassay determination of testosterone (Assay Designs, Ann Arbor, MI).

Animal behavior. Singly housed 2- to 12-month-old $D d o^{-1-}$ mice (or littermate controls) were provided ad libitum access to food and filtered tap water. Mice were maintained on a 14/10 h light/dark cycle, and weights were recorded at regular intervals. Mice acclimated to the laboratory for 2 weeks before testing under a "darkroom safe" red light during early dark phase.

Mice were videotaped and scored off-line using Observer 5.0 (Noldus Information Technology, Wageningen, The Netherlands) by a blinded scorer. The elevated plus maze test was initiated with mice placed in the center of the maze facing one of the open arms. During the residentintruder aggression test, experimental animals habituated to testing area for $10 \mathrm{~min}$, and weight-matched CD-1 stimulus males were introduced for $10 \mathrm{~min}$. Aggressive encounters were defined as biting, grappling, kicking, boxing, and mounting. Autogrooming was defined as selfdirected licking of paws, fur, tail, and genital region as well as washing motions of the head.

To assess copulatory behavior, males were introduced into the cage of a bilaterally ovariectomized CD-1 female made estrous by injection of estradiol benzoate $(50 \mu \mathrm{g})$ and progesterone $(0.5 \mathrm{mg})$ in $0.1 \mathrm{ml}$ of corn oil $2 \mathrm{~d}$ and $5 \mathrm{~h}$, respectively, before testing. Mounts were defined as males assuming the copulatory position but failing to achieve intromission. Intromission was defined as males mounting the female in association with rhythmic thrusting. Ejaculation was defined as vigorous thrusting combined with the male removing his paws from the female's back before withdrawal. Ejaculation was verified by the presence of a $>5$ min refractory period before the next mount.

\section{Results}

We created a conventional knock-out of Ddo with a genetargeting vector designed to eliminate exon 3 (Fig. 1A). Southern blots demonstrate generation of heterozygous $\left(\mathrm{Ddo}^{+/-}\right)$and homozygous $\left(D d o^{-/-}\right)$knock-out mice (Fig. 1A). Northern blots reveal a complete absence of full-length $D d o$ transcript in $D d o^{-/-}$ mice (Fig. $1 B$ ). Western blots confirm the absence of Ddo protein in $D d o^{-1-}$ mice (Fig. 1C).

Amino acid analysis demonstrates striking increases in D-aspartate levels in $D d o^{-/-}$mice. In both 4 -week-old and 4-month-old $D d o^{-1-}$ mice, D-aspartate levels are elevated 25- to 300 -fold in kidney, brain, adrenals, and ovaries (Figs. $2 A-E, \mathrm{~S} 1$, available at www.jneurosci.org as supplemental material). In contrast, there is only a twofold increase in D-aspartate levels (with a parallel decline in L-aspartate levels) in the testes, a tissue 
in which wild-type mice normally display considerable D-aspartate levels (Fig. 2F). In $\mathrm{Ddo}^{+/-}$mice, kidney $\mathrm{D}$-aspartate levels elevate threefold, in contrast to a 150-fold increase in $\mathrm{Ddo}^{-1-}$ mice (Fig. $2 \mathrm{~A}$ ). Although rat adrenals possess $\mathrm{D}$-aspartate (Hashimoto and Oka, 1997), no $\mathrm{D}$-aspartate is detectable in wild-type mouse adrenals (Fig. 2D). HPLC analysis reveals no changes in the levels of any other D- or L-amino acid in the above measured tissues (data not shown).

Given the high levels of wild-type testicular D-aspartate, we wondered whether the testes might serve as the sole source of mouse D-aspartate. However, castration of 4-month-old $D d o^{-1-}$ mice does not diminish $D d o^{-1-}$ kidney D-aspartate levels [castrated $(n=6), 598 \pm 129$ nmoles $/ g$ wet weight; sham-castrated $(n=3), 581 \pm$ 69 nmoles/g wet weight; $p=0.93$ ]. Additionally, although some studies have suggested a role for testicular D-aspartate in regulating testosterone synthesis (Nagata et al., 1999), we fail to detect altered serum testosterone concentrations in $\mathrm{Ddo}{ }^{-/-}$mice $\left(D d o^{+/+}, 1.30 \pm 0.24 \mathrm{ng} / \mathrm{ml} ; D d o^{-/-}\right.$, $1.01 \pm 0.14 \mathrm{ng} / \mathrm{ml} ; p=0.23 ; n=10$ ).

Immunohistochemical localizations of D-aspartate in wild-type mice resemble results described previously in rats (Schell et al., 1997; Sakai et al., 1998). D-Aspartate in wild-type mice localizes to cerebral cortical neurons, hippocampal CA3/CA2 neurons, neurons in the hilum of the dentate gyrus, hypothalamic PVN and SON neurons, pinealocytes, and elongate spermatids (Figs. S2, S3, available at www.jneurosci.org as supplemental material). Unlike the juvenile rat (Schell et al., 1997), D-aspartate is not immunohistochemically detected in the 4-week-old wildtype mouse adrenals (Fig. S3, available at www.jneurosci.org as supplemental material). In $\mathrm{Ddo}{ }^{-1-}$ mice, stronger $\mathrm{D}$-aspartate labeling is found in cerebral cortical neurons, hippocampal neurons, pinealocytes, and elongate spermatids (Figs. S2, S3, available at www.jneurosci.org as supplemental material). New D-aspartate labeling in the $D d o^{-1-}$ mice, undetectable in wildtype mice, is observed in adrenal medulla epinephrine cells, renal Bowman's capsule, renal thin limbs of the loops of Henle, and testicular Leydig cells (Figs. S2, S3, available at www.jneurosci.org as supplemental material). At our level of microscopic resolution, D-aspartate in wild-type and $D d o^{-1-}$ brain and peripheral tissues appears diffusely throughout cells and neuronal processes.

In the pituitary IL, we observe a striking phenotype in the $D d o^{-1-}$ mice. In wild-type mice, $D d o$ is normally expressed in the IL (Fig. $3 A$ ), explaining the negligible levels of $D$-aspartate in the wild-type IL (Fig. 3B). Wild-type D-aspartate staining is instead dense in fibers of the pituitary PL that arise from the D-aspartate-enriched hypothalamic SON and PVN cell bodies and in isolated cells of the AL (Fig. $3 B$ ). In $D d o^{-1-}$ mice, which lack pituitary IL Ddo (Fig. 3A), D-aspartate increases dramatically in the IL but only modestly in the AL and PL (Fig. $3 B$ ). Because pituitary IL melanotropes generate POMC as the source of pituitary $\alpha$-MSH, we wondered whether the augmented IL D-aspartate influences POMC/ $\alpha$-MSH. In $D d o^{-/-}$pituitary IL,
POMC expression is substantially reduced as judged by in situ hybridization (Fig. 3C). This reduction is specific, because we observe no changes in either POMC expression or the number of $P O M C$-positive neurons in $D d o^{-1-}$ pituitary $\mathrm{AL}$ (data not shown) or arcuate nucleus of the hypothalamus (Fig. 3D). Moreover, pituitary POMC protein (Fig. 3E) is markedly diminished by Western blot, and $\alpha$-MSH levels are decreased as judged by both dot blot assays and immunofluorescence (Fig. $3 F, G$ ).

Because $\alpha$-MSH influences autogrooming (Spruijt et al., 1992), penile function (Martin and MacIntyre, 2004), and weight homeostasis (Vergoni et al., 2000), we monitored these parameters in $D d o^{-1-}$ mice (Fig. 4A-D). At 2, 7, and 12 months of age, $D d o^{-1-}$ mice are significantly heavier than wild-type litter-mate controls (Fig. 4A). Ddo ${ }^{-1-}$ males also display diminished sexual behavior, as evidenced by increased latencies by males to mount and intromit females (Fig. $4 B$ ) and by severe failure of ejaculation $\left(D d o^{+/+}, 75 \pm 16.4 \% ; D d o^{-/-}, 12.5 \pm 12.5 \%\right.$ of mice that successfully ejaculate during first hour of testing; $p=0.009 ; n=8$ ). During the resident-intruder aggression test (Fig. 4C) and elevated plus maze test (Fig. $4 D$ ), Ddo ${ }^{-1-}$ mice spend nearly fourfold less time autogrooming than wild-type controls. This effect is selective as judged by the absence of changes in $\alpha$-MSHindependent allogrooming (Fig. 4D).

\section{Discussion}

Through genetic inactivation of $D d o$ in mouse, we observe massive and selective elevation of D-aspartate across the body. Ddo enzymatic activity was first identified before D-enantiomer amino acids were believed to be endogenously synthesized in 

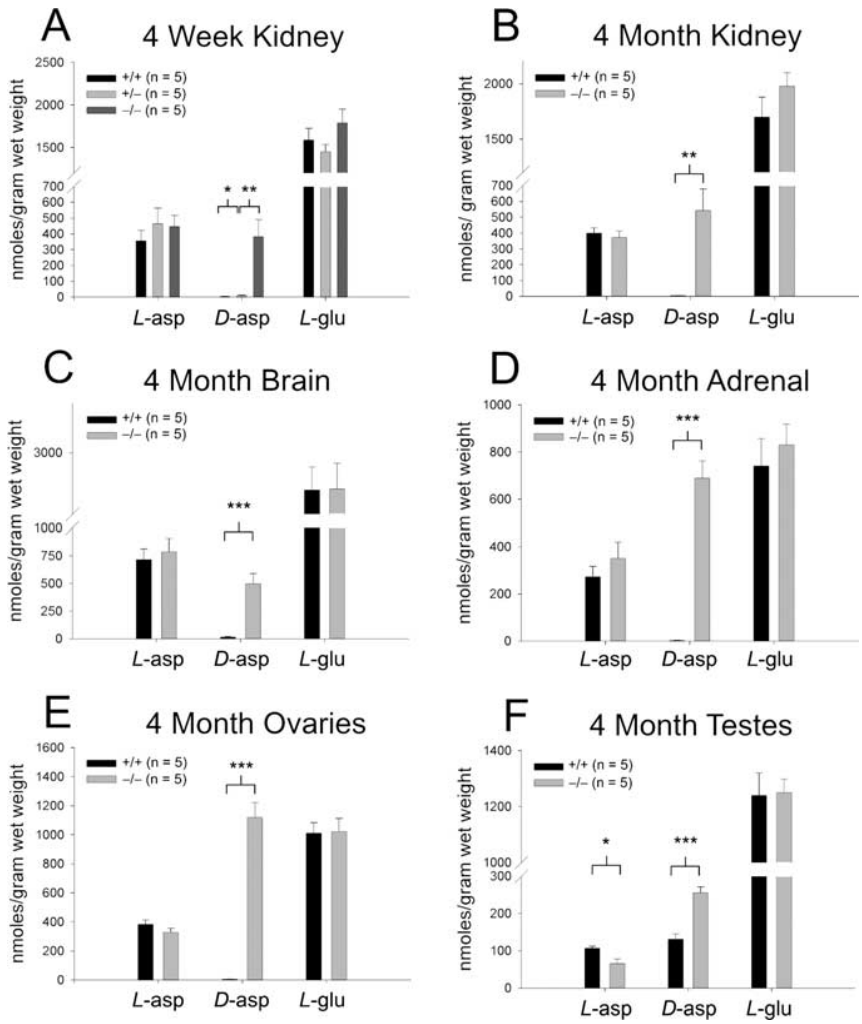

Figure 2. $D d 0^{-/-}$mice display elevated D-aspartate levels. $A, H P L C$ amino acid analysis of 4-week-old kidney D-aspartate (Ddo ${ }^{+/+}$vs D do ${ }^{+/-}, p=0.021 ; D \mathrm{do}^{+/-}$vs D do ${ }^{-/-}, p=0.008$ ). $B$, Four-month-old kidney D-aspartate ( $D d 0^{+/+}$vs $\left.D d 0^{-1-} ; p=0.004\right)$. C, Four-month-old brain D-aspartate $\left(D d o^{+/+}\right.$vs Ddo $\left.{ }^{-/-} ; p=0.0009\right)$. D, Four-month-old adrenal D-aspartate (Ddo ${ }^{+/+}$vs $\left.D d 0^{-1-} ; p=0.00001\right)$. $E$, Four-month-old ovarian D-aspartate $\left(D d o^{+/+}\right.$vs $D d 0^{-1-} ; p=$ 0.000004). $\boldsymbol{F}$, Four-month-old testicular D-aspartate $\left(D d 0^{+/+}\right.$vs $\left.D d 0^{-1-} ; p=0.0001\right)$ and $\mathrm{L}^{-}$ aspartate $\left(D d o^{+/+}\right.$vs Ddo $\left.{ }^{-1-} ; p=0.013\right) .{ }^{*} p<0.05 ;{ }^{* *} p<0.01 ;{ }^{* * *} p<0.001$; comparison with two-tailed Student's $t$ test; data are expressed as mean \pm SEM.

mammals (Still et al., 1949). Therefore, the D-amino acid oxidizing property of Ddo was considered nonphysiologic, and unsuccessful efforts were made to find possible endogenous functions (Burns et al., 1984). With orders of magnitude D-aspartate elevation in $\mathrm{Ddo}{ }^{-/-}$mice, this study clearly demonstrates that Ddo is the endogenous enzyme responsible for metabolizing D-aspartate.

Reciprocally high and low tissue concentrations occur for Ddo and D-aspartate, resembling Dao and D-serine (Snyder and Kim, 2000). Negligible levels of endogenous D-aspartate in Ddoenriched organs had implied that D-aspartate lacks important physiologic functions in these areas (Schell et al., 1997). The pronounced increase in $D d o^{-/-}$mice of D-aspartate in Ddo-enriched organs suggests that D-aspartate is physiologically relevant and turns over rapidly because of high Ddo activity. Conversely, the source of D-aspartate may come from endogenous synthesis by an unidentified aspartate racemase, because $D d o^{-/-}$testes show increased D-aspartate concomitant to decreased L-aspartate. Conversion of L-aspartate to $\mathrm{D}$-aspartate has been reported in rat cerebral cortical cultures (Wolosker et al., 2000) and invertebrates (D'Aniello et al., 2003).

One potential function for D-aspartate is observed in the pituitary IL. The $D d o^{-/-}$IL displays elevated D-aspartate levels with diminished POMC expression and $\alpha$-MSH formation. Introcerebroventricular injection of $\alpha$-MSH increases autogrooming (Spruijt et al., 1992), enhances penile erection (Martin and MacIntyre, 2004), and elicits anorexia/weight loss (Vergoni et al., 2000). Genetic inactivation of a principal brain $\alpha$-MSH receptor, melanocortin receptor 4, leads to adult-onset hyperphagiainduced obesity (Huszar et al., 1997) and sexual deficits resembling $D d o^{-/-}$mice (Van der Ploeg et al., 2002). Genetic inactivation of the other major brain $\alpha$-MSH receptor, melanocortin receptor 3, leads to increased fat mass and decreased lean mass (Butler et al., 2000; Chen et al., 2000). The elevated body mass, sexual deficits, and decreased autogrooming in $\mathrm{Ddo} \mathrm{o}^{-1-}$ mouse are consistent with their diminished $\alpha$-MSH levels

How might D-aspartate influence POMC expression and other targets? Nagata and coworkers (1999) showed that D-aspartate stimulation of testosterone formation in Leydig cell cultures is abolished by inhibition of glutamate transport, implying that D-aspartate is transported into target cells rather than acting at surface receptors. Conceivably, a similar mechanism mediates D-aspartate actions on melanotropes.
A
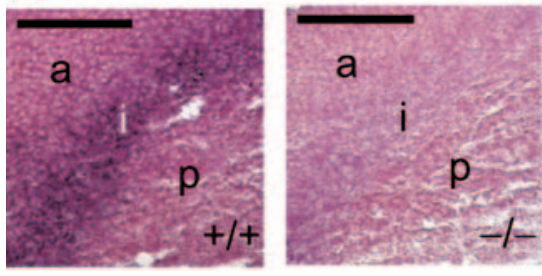

B

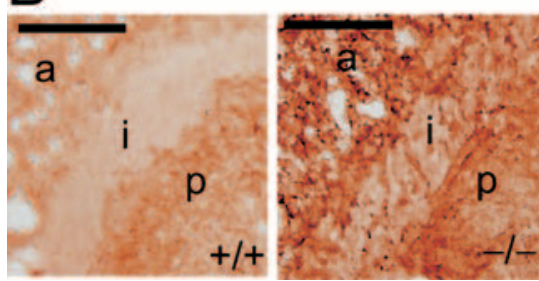

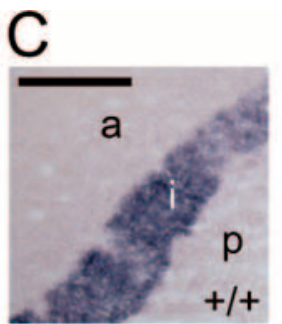
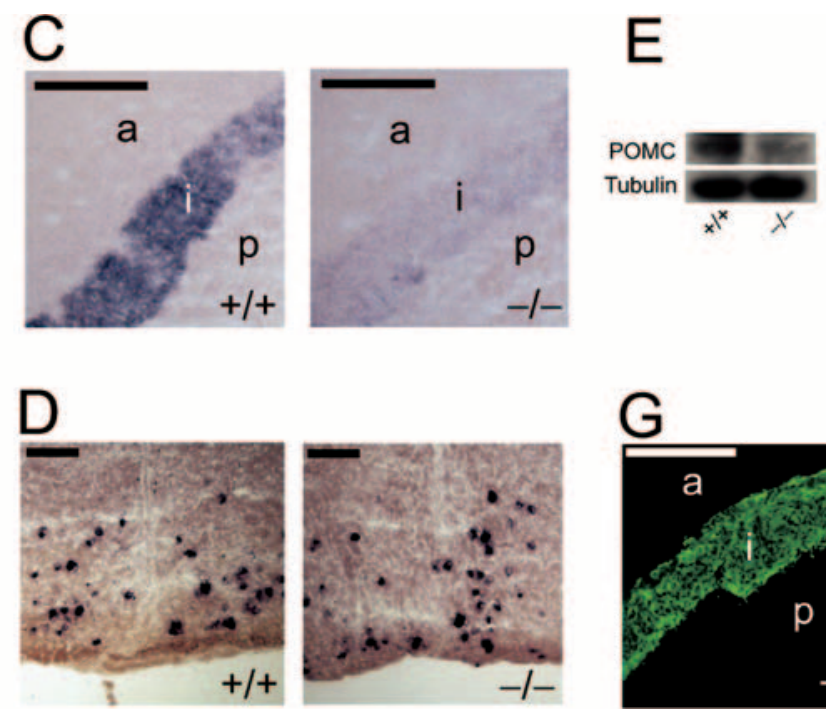

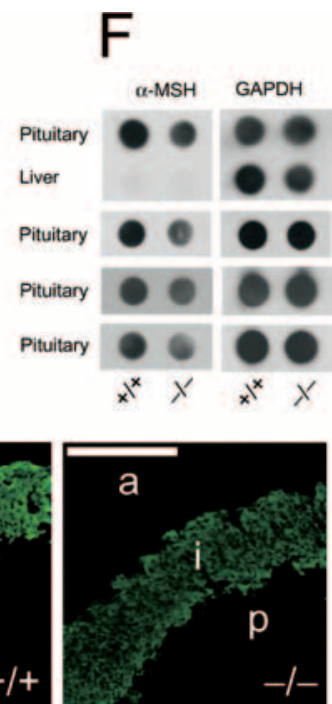

Figure 3. Elevated D-aspartate in $D d 0^{-1-}$ mice pituitary intermediate lobe is associated with diminished melanocortin levels. $\boldsymbol{A}, \mathrm{Ddo}$ in situ hybridization $(n=2) . \boldsymbol{B}, \mathrm{D}-\mathrm{Aspartate}$ immunohistochemistry $(n=4)$. $\boldsymbol{C}, \boldsymbol{D}$, POMC in situ hybridization in the pituitary $(\boldsymbol{C} ; n=3)$ and arcuate nucleus $(\boldsymbol{D} ; n=2) . \boldsymbol{E}$, POMC Western blot of crude pituitary lysate $(n=2) . \boldsymbol{F}, \boldsymbol{G}$, Crude pituitary lysate $\operatorname{dot} \operatorname{blot}(\boldsymbol{F} ; n=4)$ and immunofluorescence $(\boldsymbol{G} ; n=2)$ of $\alpha$-MSH. Scale bars, $100 \mu \mathrm{m}$. a, Anterior lobe; i, intermediate lobe; p, posterior lobe. 
Many studies of melanocortindependent behaviors focus on hypothalamic arcuate-synthesized $\alpha$-MSH acting on central melanocortin receptors (Cone et al., 2001). Ddo ${ }^{-/-}$mice do not display altered $P O M C$ expression in the arcuate nucleus, suggesting that decreased melanocortin-dependent behaviors in $D d o^{-/-}$mice do not reflect centrally derived melanocortins but may involve pituitary $\alpha$-MSH influencing central $\alpha$-MSH tone.

Pituitary signaling back to the brain and hypothalamus, a controversial concept, may involve either direct retrograde blood flow from the pituitary back to the hypothalamus or filtration/secretion of peptides into the CSF via subarachnoid or choroid plexus routes (Assies et al., 1978; Page, 1982). Injection of radiolabeled $\alpha-\mathrm{MSH}_{4-9}$, the bioactive portion of the 12 amino acid peptide, into the pituitary leads to its accumulation across the brain with highest levels in hypothalamic areas such as the arcuate nucleus, $\mathrm{SON}$, and median eminence (Mezey et al., 1978). After pituitary stalk sectioning, accumulation of radiolabeled peptide diminishes selectively in the hypothalamus but then returns after vascular regeneration (Mezey et al., 1978). Lesion studies imply that high levels of $\alpha$-MSH in portal plasma arise from the pituitary (Oliver et al., 1977; Paradisi et al., 1993). Various conditions that elevate $\alpha$-MSH in serum also augment $\alpha$-MSH in the brain (De Rotte et al., 1980).

Lesion studies also establish a role for the pituitary in melanocortin-dependent behaviors. Hypophysectomized rats display reduced melanocortin-regulated erections and autogrooming (Dunn et al., 1979; Argiolas et al., 1987). Exitotoxic ablation of the arcuate nucleus has no effect (Dunn et al., 1985; Argiolas et al., 1987).

Although pituitary $\alpha$-MSH may influence behavior, arcuatederived $\alpha$-MSH is better established as a dominant mediator of melanocortin-dependent behaviors, which is evident in our study. Body weight doubles in POMC-deficient, mice reflecting the total effect of melanocortins (Yaswen et al., 1999). In contrast, $D d o^{-/-}$mice display a $15-18 \%$ increased weight gain, presumably reflecting a lesser role of pituitary than arcuate $\alpha$-MSH.

In summary, our findings indicate potential physiologic roles for D-aspartate in neuroendocrine function. We establish that D-aspartate is an endogenous substrate of Ddo and that D-aspartate turns over rapidly as a result of Ddo activity. D-Aspartate presumably decreases pituitary $\alpha$-MSH levels by regulating POMC biosynthesis, which then leads to alterations in behaviors known to be mediated by $\alpha-\mathrm{MSH}$.

\section{References}

Argiolas A, Melis MR, Fratta W, Mauri A, Gessa GL (1987) Monosodium glutamate does not alter ACTH- or apomorphine-induced penile erection and yawning. Pharmacol Biochem Behav 26:503-507.

Assies J, Schellekens AP, Touber JL (1978) Protein hormones in cerebrospinal fluid: evidence for retrograde transport of prolactin from the pituitary to the brain in man. Clin Endocrinol (Oxf) 8:487-491.

Burns CL, Main DE, Buckthal DJ, Hamilton GA (1984) Thiazolidine-2- carboxylate derivatives formed from glyoxylate and L-cysteine or L-cysteinylglycine as possible physiological substrates for D-aspartate oxidase. Biochem Biophys Res Commun 125:1039-1045.

Butler AA, Kesterson RA, Khong K, Cullen MJ, Pelleymounter MA, Dekoning J, Baetscher M, Cone RD (2000) A unique metabolic syndrome causes obesity in the melanocortin-3 receptor-deficient mouse. Endocrinology 141:3518-3521.

Chen AS, Marsh DJ, Trumbauer ME, Frazier EG, Guan XM, Yu H, Rosenblum CI, Vongs A, Feng Y, Cao L, Metzger JM, Strack AM, Camacho RE, Mellin TN, Nunes CN, Min W, Fisher J, Gopal-Truter S, MacIntyre DE, Chen HY, et al. (2000) Inactivation of the mouse melanocortin-3 receptor results in increased fat mass and reduced lean body mass. Nat Genet 26:97-102.

Cone RD, Cowley MA, Butler AA, Fan W, Marks DL, Low MJ (2001) The arcuate nucleus as a conduit for diverse signals relevant to energy homeostasis. Int J Obes Relat Metab Disord 25 [Suppl 5]:S63-S67.

D’Aniello A, Spinelli P, De Simone A, D'Aniello S, Branno M, Aniello F, Fisher GH, Di Fiore MM, Rastogi RK (2003) Occurrence and neuroendocrine role of D-aspartic acid and N-methyl-D-aspartic acid in Ciona intestinalis. FEBS Lett 552:193-198.

De Rotte AA, Bouman HJ, van Wimersma Greidanus TB (1980) Relationships between alpha-MSH levels in blood and in cerebrospinal fluid. Brain Res Bull 5:375-381.

Dunlop DS, Neidle A, McHale D, Dunlop DM, Lajtha A (1986) The presence of free D-aspartic acid in rodents and man. Biochem Biophys Res Commun 141:27-32.

Dunn AJ, Green EJ, Isaacson RL (1979) Intracerebral adrenocorticotropic hormone mediates novelty-induced grooming in the rat. Science 203:281-283.

Dunn AJ, Webster EL, Nemeroff CB (1985) Neonatal treatment with monosodium glutamate does not alter grooming behavior induced by novelty or adrenocorticotropic hormone. Behav Neural Biol 44:80-89.

Hadley ME, Haskell-Luevano C (1999) The proopiomelanocortin system. Ann NY Acad Sci 885:1-21.

Hara MR, Agrawal N, Kim SF, Cascio MB, Fujimuro M, Ozeki Y, Takahashi M, Cheah JH, Tankou SK, Hester LD, Ferris CD, Hayward SD, Snyder SH, 
Sawa A (2005) S-nitrosylated GAPDH initiates apoptotic cell death by nuclear translocation following Siah1 binding. Nat Cell Biol 7:665-674.

Hashimoto A, Oka T (1997) Free D-aspartate and D-serine in the mammalian brain and periphery. Prog Neurobiol 52:325-353.

Hashimoto A, Nishikawa T, Konno R, Niwa A, Yasumura Y, Oka T, Takahashi K (1993) Free D-serine, D-aspartate and D-alanine in central nervous system and serum in mutant mice lacking D-amino acid oxidase. Neurosci Lett 152:33-36.

Huszar D, Lynch CA, Fairchild-Huntress V, Dunmore JH, Fang Q, Berkemeier LR, Gu W, Kesterson RA, Boston BA, Cone RD, Smith FJ, Campfield LA, Burn P, Lee F (1997) Targeted disruption of the melanocortin-4 receptor results in obesity in mice. Cell 88:131-141.

Lee JA, Homma H, Tashiro K, Iwatsubo T, Imai K (1999) D-Aspartate localization in the rat pituitary gland and retina. Brain Res 838:193-199.

Martin WJ, MacIntyre DE (2004) Melanocortin receptors and erectile function. Eur Urol 45:706-713.

Mezey E, Palkovits M, de Kloet ER, Verhoef J, de Wied D (1978) Evidence for pituitary-brain transport of a behaviorally potent ACTH analog. Life Sci 22:831-838.

Nagata Y, Homma H, Lee JA, Imai K (1999) D-Aspartate stimulation of testosterone synthesis in rat Leydig cells. FEBS Lett 444:160-164.

Oliver C, Mical RS, Porter JC (1977) Hypothalamic-pituitary vasculature: evidence for retrograde blood flow in the pituitary stalk. Endocrinology 101:598-604.

Page RB (1982) Pituitary blood flow. Am J Physiol 243:E427-E442.

Paradisi R, Frank G, Magrini O, Capelli M, Venturoli S, Porcu E, Flamigni C (1993) Adeno-pituitary hormones in human hypothalamic hypophysial blood. J Clin Endocrinol Metab 77:523-527.

Sakai K, Homma H, Lee JA, Fukushima T, Santa T, Tashiro K, Iwatsubo T,
Imai K (1998) Localization of D-aspartic acid in elongate spermatids in rat testis. Arch Biochem Biophys 351:96-105.

Schell MJ, Cooper OB, Snyder SH (1997) D-Aspartate localizations imply neuronal and neuroendocrine roles. Proc Natl Acad Sci USA 94:2013-2018.

Simonic T, Duga S, Negri A, Tedeschi G, Malcovati M, Tenchini ML, Ronchi $\mathrm{S}$ (1997) cDNA cloning and expression of the flavoprotein D-aspartate oxidase from bovine kidney cortex. Biochem J 322:729-735.

Snyder SH, Kim PM (2000) D-Amino acids as putative neurotransmitters: focus on D-serine. Neurochem Res 25:553-560.

Spruijt BM, van Hooff JA, Gispen WH (1992) Ethology and neurobiology of grooming behavior. Physiol Rev 72:825-852.

Still JL, Buell MV, Knox WE, Green DE (1949) Studies on the cyclophorase system: VII. D-Aspartate oxidase. J Biol Chem 179:831-837.

Van der Ploeg LH, Martin WJ, Howard AD, Nargund RP, Austin CP, Guan X, Drisko J, Cashen D, Sebhat I, Patchett AA, Figueroa DJ, DiLella AG, Connolly BM, Weinberg DH, Tan CP, Palyha OC, Pong SS, MacNeil T, Rosenblum C, Vongs A, et al. (2002) A role for the melanocortin 4 receptor in sexual function. Proc Natl Acad Sci USA 99:11381-11386.

Vergoni AV, Schioth HB, Bertolini A (2000) Melanocortins and feeding behavior. Biomed Pharmacother 54:129-134.

Wolosker H, Blackshaw S, Snyder SH (1999) Serine racemase: a glial enzyme synthesizing $\mathrm{D}$-serine to regulate glutamate- $N$-methyl-D-aspartate neurotransmission. Proc Natl Acad Sci USA 96:13409-13414.

Wolosker H, D’Aniello A, Snyder SH (2000) D-Aspartate disposition in neuronal and endocrine tissues: ontogeny, biosynthesis and release. Neuroscience 100:183-189.

Yaswen L, Diehl N, Brennan MB, Hochgeschwender U (1999) Obesity in the mouse model of pro-opiomelanocortin deficiency responds to peripheral melanocortin. Nat Med 5:1066-1070. 